\title{
FEDERAL ARBITRATION ACT AND APPLICATION OF THE "SEPARABILITY DOCTRINE" IN FEDERAL COURTS
}

The classification of arbitration as "substantive" in Bernhardt v. Polygraphic Company jeopardized application of the federal Arbitration Act in diversity cases. However, in the recent case of Prima Paint Corporation v. Flood \& Conklin Manufacturing Company, the Supreme Court found the Act to be a legitimate exercise of the federal commerce power and, hence, applicable in diversity cases involving arbitration agreements contained in interstate contracts. Furthermore, in interpreting the Act, the Court ruled that an arbitration provision is severable from other portions of an agreement for purposes of adjudicating contractual validity. However, by speaking only of federal court enforcement of the Act, the Court may have created severe forum-shopping problems. In order to avoid these problems, and vindicate the policy behind the Act, the coverage of the Act may subsequently be extended to the states.

$\mathbf{T}$ he Supreme Court's classification of arbitration as "substantive" in nature ${ }^{1}$ jeopardized successful invocation of the federal Arbitration Act $^{2}$ in cases in which jurisdiction was based on diversity of citizenship. Consistent with that classification, the Erie-Guaranty Trust doctrine ${ }^{3}$ seemingly inandated that state law govern judicial treatment of an arbitration agreement in simple diversity cases. Recently, however, in Prima Paint Corporation v. Flood \& Conklin Manufacturing Company, ${ }^{4}$ the Supreme Court held the Act properly applicable to diversity cases involving contracts in interstate cominerce, refusing to consider referent state contract law. ${ }^{5}$ In interpreting the Act, the Court ruled that an arbitration provision is severable from other portions of an agreement for purposes of adjudicating contractual validity: issues which go to the enforceability of the entire contract will be resolved by the arbitrator, while the validity of the "making" of the arbitration clause itself will be judicially determined.6

1 See Bernhardt v. Polygraphic Co., 350 U.S. 198, 202-04 (1956); Note, 69 YALE L.J. 847, 848, 864-67 (1960).

29 U.S.C. \$§ 1-14 (1964). See notes 21-32 infra and accompanying text.

${ }^{3}$ See notes 33-41 infra and accompanying text.

4388 U.S. 395 (1967).

${ }^{5} \mathrm{Id}$. at 404-05. See notes 85-87 infra and accompanying text.

${ }^{6} 388$ U.S. at 403-04, 406. See notes 48-51 \& 62-67 infra and accompanying text. 
Having concluded, in effect, that the "separability doctrine" was inherent in the "substantive rules" of the Arbitration Act, the majority found constitutional warrant for the Act in the congressional power to regulate the practice of the federal courts in dealing with disputes arising in interstate commerce. ${ }^{7}$ However, the Court spoke only of federal court enforcement of arbitration agreements contained in contracts involving interstate commerce. ${ }^{8}$ Thus, the Act may arguably be subject to an equal protection attack by those who, because of the jurisdictional requirements of the Act and the general federal removal statute, cannot gain access to the local federal court and are, therefore, vulnerable to state court hostility toward antecedent arbitration agreennents. ${ }^{9}$ For this reason, and in order to curb further judicial resistance to arbitration, the Court may eventually extend the coverage of the Act to the states as a matter of "national substantive law."10

Petitioner Prima Paint contracted to purchase the interstate paint business of respondent Flood \& Conklin. To facilitate the change in ownership, the parties entered into a consulting agreement, ${ }^{11}$ which included

' 388 U.S. at 405. See notes 85-87 infra and accompanying text. The Prima Court does not expressiy adopt the terminology of the Second :Circuit in Robert Lawrence Co. v. Devonshire Fabrics, Inc., 271 F.2d 402 (2d Cir. 1959), that arbitration agreements were "separable" from the rest of the contract, id. at 410 . However, since the Supreme Court did reach the same result, the use of the term "separability doctrine" would seem justifiable. See note 53 infra. The First Circuit, which refused to uphold a federal "separability doctrine," see note 54 infra, noted the possibility of such a doctrine under the New York Arbitration Act, N.Y. CTv. PrAc. LAw §§ 7501-14 (McKinney 1963), which served as the model for the Arbitration Act. Lummus Co. v. Commonwealth Oil Ref. Co., 280 F.2d 915, 923-27 (1st Cir.), cert. denied, 364 U.S. 911 (1960).

${ }^{s} 388$ U.S. at 403 . See notes $89-90$ infra and accompanying text.

${ }^{9}$ See text following note 89 infra. At the present time, twenty-seven states will not enforce a written agreement to settle a future dispute by arbitration. A number of jurisdictions will enforce a present agreement to arbitrate, see, e.g., DEL. CODE ANN. tit. 10, \$§ 5701-06 (1953); IND. ANN. STat. §§ 3-201 to -226 (1946); Kan. Stat. ANN. $\$ \$ 5-201$ to -213 (1963); Mrss. Code ANN. $\$ \$ 279-97$ (1956), or will do so if the agreement has been submitted in writing to the court, see, e.g., GA. CoDE ANN. \$\$ 7-101 to -224 (1933); N. C. GeN. Stat. \$\& 1-544 to -567 (1951); VA. Code ANN. $\$ \$ 8-503$ to -507 (1957). Three states-Alaska, Oklahoina, and Vermont-have no statutory provisions for commercial arbitration. The legislative enactments in Maine and New Mexico, on the other hand, provide inadequate substitutes for the procedural safeguards incorporated in the Arbitration Act for situations arising after an arbitration agreement has been held valid, such as failure to agree on an arbitrator or application for enforcement of an award. Compare ME. REv. STAT. ANN. tit. 14, \$§ 1151-55 (1964), and N. M. STAT. ANN. $\S 22-3-1$ to -8 (1953), with Arbitration Act, 9 U.S.C. \$§ 3-13 (1964). See also notes 25-29 infra and accompanying text.

${ }^{10}$ See text accompanying notes 90-120 infra.

11 In an affidavit submitted to the District Court for the Southern District of New York, the president of Prima Paint stated that the consulting agreement was designed to 
a broad arbitration clause encompassing any disputes arising out of "this Agreement." ${ }^{12}$ When a controversy arose under the consulting arrangement, Flood \& Conklin requested arbitration..$^{13}$ Invoking diversity jurisdiction, ${ }^{14}$ Prima sought recission of the consulting provision in a federal district court, alleging fraud in the inducement of that agreement. Flood \& Conklin then moved for a stay of legal proceedings pending arbitration as provided by section 3 of the Act. ${ }^{15}$

In granting the motion to stay, the district court found the arbitration clause sufficiently broad to require arbitral determination of the validity of the consulting agreement and, relying upon the "separability doctrine," held that Prima's claim of fraud in the inducement of the contract generally was a question for the arbiters, although a specific identical allegation with respect to the arbitration clause would have required judicial resolution. ${ }^{16}$ The Court of Appeals for the Second Circuit denied Prima's appeal ${ }^{17}$ and the Supreme Court affirmed the dismissal. While agreeing that the Arbitration Act mandated application of the principles of separability in the federal courts, the Supreme Court located the source of those precepts in section 4 of the Act, rather than in the substantive provisions of section 2.18

effectuate "an orderly transfer of the assets of the defendant $[F \& C]$ to the plaintiff [Prima Paint], and [the agreement] contemplated and intended that the defendant would consult, advise, assist and help the plaintiff so as to insure a smooth transition of manufacturing operations ...., together with the sales and servicing of customer accounts and the retention of the said customers." 388 U.S. at 401 n.6. See text following note 55 infra.

12388 U.S. at 398 . The pertinent portion of the arbitration agreement stated: "Any controversy or claim arising out of or relating to this Agreement, or the breaeh thereof, shall be settled by arbitration in the City of New York, in accordance with the rules then obtaining of the American Arbitration Association. . . ."

${ }^{13} \mathrm{Id}$. Prima Paint refused to pay' the first installment due under the purchase agreement, claiming that $\mathrm{F} \& \mathrm{C}$ bad fraudulently misrepresented itself as solvent. In fact, a week after the sales contract bad been signed, and before the consulting agreement was entered into, F \& C filed a voluntary petition for bankruptcy under Chapter XI of the Bankruptcy Act, 11 U.S.C. $\S \S 701-1255$ (1964). In a letter to F \& C's attorneys, Prima Paint alleged fraudulent inducement of both contracts. However, in the actual suit for recision filed by Prima Paint, the complaint referred to fraudulent inducement of the consulting agreement alone. 388 U.S. at 398-99.

14 Prima Paint was a Maryland corporation, while F \& C was incorporated in New Jersey. 388 U.S. at 397.

${ }^{15}$ Id. at 399; Arbitration Act, 9 U.S.C. $\$ 3$ (1964). See note 26 infra.

${ }^{16}$ Prima Paint Corp. v. Flood \& Conklin Mfg. Co., 262 F. Supp. 605, 606-07 (S.D.N.Y. 1966). See also Robert Lawrence Co. v. Devonshire Fabrics, Inc., 271 F. 2d 402, 410 (2d Cir. 1959); text accompanying notes 62-67 infra.

17360 F.2d 315, 318 (2d Cir. 1966).

${ }^{18}$ Compare 388 U.S. at 403-05, with Robert Lawrence Co. v. Devonshire Fabrics, Inc., 271 F. 2d 402, 409-10 (2d Cir. 1959). See notes 49-54 \& 62-69 infra and accompanying text. 
Moreover, the Court chose not to extend the Act to the states, ${ }^{19}$ despite dictum favoring extension in several earlier circuit court opinions. ${ }^{20}$

The Arbitration Act divides naturally into two segments. Sections 1 and 2 set forth in broad, substantive terms the congressional desire to quell traditional judicial hostility to arbitration. ${ }^{21}$ Thus, section 2 makes "valid,

10388 U.S. at 403, 406. See note 90 infra. Justice Harlan would have affirmed on the basis of Lawrence. Id. at 407 (concurring opinion).

${ }^{20}$ See Robert Lawrence Co. v. Devonshire Fabrics, Inc., 271 F. 2d 402, 407 (2d Cir. 1959); cases cited note 52 infra.

21 See 9 U.S.C. \$§ 1-2 (1964); CoMmitTeE on the Judictary, To Make VaLID and ENforceable Certain Agreements for Arbitration, S. Rep. No. 536, 68th Cong., 1st Sess. 2-3 (1924); Committee on Commerce, Trade and Commercial Law, The United States Arbitration Law and Its Application, 11 A.B.A.J. 153, 155 (1925); Note, Commercial Arbitration in Federal Courts, 20 VAND. L. Rev. 607, 608-09 (1967).

The Arbitration Act became law in 1925 at the urging of various business interests and under the sponsorship of the American Bar Association. Patterned after the New York Arbitration Act of 1921, it was hoped that the Act would reduce'litigation, thereby decreasing the delays and expenses incumbent to any formal judicial settling of disputes, and would permit the use of business expertise in the settlement of essentially technical controversies. See Baum \& Pressman, The Enforcement of Commercial Arbitration Agreements in the Federal Courts (pt.1), 8 N.Y.U.L.Q. 238, 249-50 (1930); Bernheimer, The United States Arbitration Act, 3 DockET 2928 (1925); note 67 infra. As explained to congressional committees by the American Bar Association, the Arbitration Act was to be passed in conjunction with uniform state laws on arbitration, thereby removing any problem of differing state and federal law in diversity cases. See Report of Committee on Commerce, Trade and Commercial Law, 47 A.B.A. ReP. 288, 294 (1922); Report of Committee on Commerce, Trade and Commercial Law, 46 A.B.A. REP. 309, 355 (1921); cf. Joint Hearings Before the Subcomms. of the Comms. on the Judiciary on the Arbitration of Interstate Commercial Disputes, 68th Cong., 1st Sess., ser. 4, vol. 1, at 6, 16, 28 (1924). However, because of a dispute among members of the American Bar Association, the task of writing the actual uniform state law was referred to the National Conference of Commissioners on Uniform State Laws. Report of Committee on Commerce, Trade and Commercial Law, 50 A.B.A. REP. 353, 359 (1925). See id. at 135-62 for a report of the floor debate at the American Bar Conveution. The uniform law proposed by the Commissioners and subsequently passed by six states-Nevada, North Carolina, Pennsylvania, Utah, Wisconsin, and Wyoming-was considerably weaker than the Arbitration Act in that the uniform state law made valid, irrevocable, and enforceable only agreements 'to submit present controveries to arbitration. See id. at 591. See also Report of Commissioners on Uniform State Laws, 49 A.B.A. REP. 45 (1924). In 1943 this uniform law was abandoned by the Commissioners, compare list of Uniform Acts approved by the Bar Association, 67 A.B.A. REP. 452 (1942), with same list, 68 A.B.A. ReP. 528 (1943), and was replaced by a statute which is in conformity with the Arbitration Act. Report of Commissioners on Uniform State Laws, 80 A.B.A. ReP. 171 (1955). Presently, seven states bave adopted this second statute. See Ardz. REv. STAT. ANN. \$§ 12-1501 to -1517 (Supp. 1967); IlL. ANN. STAT. ch. 10, §§ 101-23 (Smith-Hurd Supp. 1967); MD. ANn. CoDE art. 7, §§ 1-23 (Supp. 1967); Mass. ANN. LaWs ch. 251, §§ 1-19 (Supp. 1966); MnNN. Stat. ANN. $\$ \$ 572.08-30$ (Supp. 1967); PA. Stat. ANN. tit. 5, $\S \S 161-181$ (1963); WYo. StaT. ANN. \$§ 1-1048.1-.21 (Supp. 1967). 
irrevocable, and enforceable" all written arbitration agreements contained in maritime transactions or contracts involving commerce, with the exception of situations where grounds "exist at law or in equity for the revocation of any contract."22 However, section 1 restricts the scope of the Act to interstate arbitration agreements by defining "commerce" as "commerce among the several States or with foreign nations."23 Accordingly, these "enabling" sections appear to be an exercise of the commerce power. ${ }^{24}$ Sections 3 through 13 constitute the "procedural" devices for implementing the Inandate of section $2 .{ }^{25}$ Section 3 authorizes any federal court to stay trial of an action pending arbitration, while section 4 grants district courts power to compel arbitration if there is a valid arbitration agreement. ${ }^{26}$ Further, the latter provision directs the courts to adjudicate a claim, rather than defer to the arbitrators, "[i]f the making of

229 U.S.C. $\$ 2$ (1964): "A written provision in any maritime transaction or a contract evidencing a transaction involving commerce to settle by arbitration a controversy thereafter arising out of such contract or transaction, or the refusal to perform the whole or any part thereof, or an agreement in writing tol submit to arbitration an existing controversy arising out of such a contract, transaction, or refusal, shall be valid, irrevocable, and enforcenble, save upon such grounds as exist at law or in equity for the revocation of any contract."

${ }^{23} I d$. $\S 1$. Section 1 provides in part: “' [C]ommerce,' as herein defined, means commerce among the several States or with foreign nations, . . . but nothing herein contained shall apply to contracts of employment of seamen, railroad enployees, or any other class of workers engaged in foreign or interstate commerce."

${ }^{24}$ See Robert Lawrence Co. v. Devonshire Fabrics, Inc., 271 F.2d 402, 406.07 (2d Cir. 1959); H. R. Rep. No. 96, 68th Cong., 1st Sess. 1 (1924); Joint Hearings, supra note 21, at 7; Sturges \& Murphy, Some Confusing Matters Relating to Arbitration Under the United States Arbitration Act, 17 LAw \& Contemp. Pros. 580, 585-98 (1952). But see Note, 46 TEXAs L. REv. 260, 262-65 (1967).

259 U.S.C. $\$ \$ 3-13$ (1964).

${ }^{26} 9$ U.S.C. $\$ 3$ (1964): "If any suit or proceeding be brought in any of the courts of the United States upon any issue referable to arbitration under an agreement in writing for such arbitration, the court in which such suit is pending, upon being satisfied that the issue involved in such suit or proceeding is referable to arbitration under such an agreement, shall on application of one of the parties stay the trial of the action until such arbitration has been had in accordance with the terms of the agreement, providing the applicant for the stay is not in default in proceeding with such arbitration."

Section 4 provides in part: "A party aggrieved [by a violation of section 2] may petition any United States district court which, save for such agreement, would have jurisdiction under Title $28, \ldots$ for an order directing that such arbitration proceed in the manner provided for in such agreement. : . . The court shall hear the parties, and upon being satisfied that the making of the agreement for arbitration or the failure to comply therewith is not in issue, the court shall make an order directing the parties to proceed to arbitration in accordance with the terms of the agreement. ... If the making of the arbitration agreement or the failure, neglect, or refusal to perform the same be in issue, the court shall proceed summarily to the trial thereof. ..." 9 U.S.C. $\$ 4$ (1964). 
the arbitration agreement' is in question. ${ }^{27}$ The subsequent sections of the Act provide for the successful completion of arbitration and enforcement of an award, limiting judicial modification or reversal to instances of obvious fraud, corruption, prejudice, or mistake on the part of the arbitrator. 28

279 U.S.C. $\$ 4$ (1964) (emphasis added). Section 4 also directs the courts to adjudicate a claim if "the failure, neglect, or refusal to perform" the arbitration agreement is in issue. While this could be construed to permit the avoidance of arbitration by a party's mere refusal to comply with the agreement, such an'interpretation would tend to subvert the purpose of the Act. Therefore, this provision might be read as allowing judicial determination only when the failure to perform is due to a dispute concerning the making of the arbitration agreement. But see Baum \& Pressman, supra note 21, at 252 .

289 U.S.C. \$\$ 5-13 (1964). Section 5 grants a federal court power to appoint an arbitrator if the parties should fail to agree, or if no provision was imcluded in the agreement for an appointment. Section 7 conveys the subpoena power to the arbitrator, whether the arbitrator be appointed by the court or selected by the parties. Section 9 provides for the enforcement of arbitration awards, and, apparently, a party to an award may file an application for federal court enforcement without meeting the normal jurisdictional requirements, see notes 94-96 infra and accompanying text, so long as the award was rendered within that court's district. However, there would seem to be no rational basis for permitting freer access to a federal remedy where an award has been made $(\$ 9)$ than where arbitration has not yet taken place $(\$ 4)$, since the statute atteinpts to validate all arbitration agreements within the confines of the Act ( $\$ 2)$, rather than merely those agreements which have attained award status.

Section 10 provides for vacation of an award: "(a) Where ... procured by corruption, fraud, or undue means. (b) Where there was evident partiality or corruption in the arbitrators ..... (c) Where the arbitrators were guilty of misconduct in refusing to postpone the hearing, upon sufficient cause shown, or in refusing to hear evidence pertinent and material to the controversy; or of any other misbehavior by 'which the rights of any party have been prejudiced. (d) Where the arbitrators exceeded their powers ... ." Section 11 gives a district court power to modify or correct an award: "(a) Where there was an evident material miscalculation ... or an evident material mistake .... (b) Where the arbitrators have awarded upon a matter not submitted to them, unless it is a matter not affecting the merits of the decision ....."

The various state statutes similarly limit the scope of judicial review of an arbitrator's award, primarily in order to prevent the undue delay and expense which arbitration is designed to avoid. See, e.g., ALA. Code tit. 7, \$ 842 (1960); MASs. ANN. LAws ch. 251, § 12 (Supp. 1966); Mo. ANN. STAT. \$§ 435.100, 435.110 (1949); WASH. Rev. CODE $\$ \$ 7.04 .160,7.04 .170$ (Supp. 1956). See also W. STURGES, Commercial ARbitrations AND Awards \$\$ 360-70 (1930); Cohen \& Dayton, The New Federal Arbitration Law, 12 VA. L. REV. 265, 273 (1926).

Such restricted judicial review. may lead to undesirable consequences, as indicated by a recent Second Circuit opinion, Standard Chlorime, Inc. v. Leonard, 384 F.2d 304 (2d Cir. 1967). After the plaintiff had brought an action in a district court for breach of contract, fraud, and recision, the defendant moved for a stay of the legal proceedings pending arbitration. The district court granted the motion, and the Second Circuit dismissed the appeal. The circuit court noted that a section 3 stay order under the Arbitration Act was not a "final decision" within 28 U.S.C. \$ 1291 (1964). Hence, the plaintiff could only prevail if the stay order fell within one of the exceptions to the finality 
Recourse to these remedies, however, is dependent upon the satisfaction of traditional jurisdictional prerequisites for entry into the federal courts. ${ }^{29}$

Congressional discussion of the Act's constitutional foundation centered upon the power given Congress in article III to regulate procedure in the federal courts. ${ }^{30}$ Had the statute been solely an exercise of that power, however, there would have been no need to limit its provisions to arbitration agreements in interstate contracts. ${ }^{31}$ Consequently, the bifurcated composition of the Act suggests that it rests on dual constitutional grounds, the article III power and the commerce clause. ${ }^{32}$

requirement contained in 28 U.S.C. $\$ 1292$ (a) (1) (1964), which provides that "Interlocutory orders ... granting, continuing, modifying, refusing or dissolving injunctions ...." are appealable. The court felt bound by the Supreme Court decision in Baltimore Contractors, Inc. v. Bodinger, 348 U.S. 176 (1955), which indicated that an order staying a suit pending arbitration was an interlocutory injunction under $\$ 1292$, and thus appealable, only if the stay sought was of a "law type action." 384 F.2d at 307. The stay of an "equity type proceeding" was to be considered an order within the legal action, and thus not appealable. Id. Characterizing, the plaintiff's complaint as equitable, the Second Circuit dismissed the appeal. Thus, due to the strict confines of judicial review under the Arbitration Act and the numcrous comparable state statutes, a party asserting merely an equitable attack upon a contract containing an enforceable arbitration agreement will obtain judicial treatment of that claim only if he is able to demonstrate corruption or obvious mistake on the part of the arbitrator. Sinco the arbitrator will be determining "legal" as well as "commercial" questions, the lack of any effective judicial review in this instance would seem highly questionable and, perhaps, an unconstitutional denial of due process. Prima Paint Corp. v.'Flood \& Conklin Mfg. Co., 388 U.S. 395, 407 (1967) (Black, J., dissenting). See notes 60 \& 67 infra.

${ }^{29}$ See notes $92-94$ infra and accompanying text.

so 388 U.S. at 418-20 \& nn.18-23 (Black, J., dissenting); see Joint Hearings, supra note 21, at 17-18, 37; cf. H.R. ReP. No. 96, 68th Cong., 1st Sess. 1 (1924); Committee on Commerce, supra note 21, at 154-55. But see 388 U.S. at 401-02 n.7, 405-06 n.13.

319 U.S.C. §§ 1-2 (1964); see Sturges \& Murphy, supra note 24, at 589; Note, 69 YALE L.J. 847, 858 (1960).

32 Committee on Commerce, supra note 21, at 154-55; note, 108 U. PA. L. REv. 915, 916, 918-19 (1960). See notes 21-28 supra and accompanying text. The limited documentary evidence available suggests that Congress was not in agrcement as to the constitutional grounds for the Act. For example, in the House report, the purpose of the bill was stated to be "to make valid and enforcible agreenients for arbitration'contained in contracts involving interstate commerce'...." On the same page, however, there appears the comment that " $[w]$ hether an agreement for arbitration shall be enforced or not is a question of procedure ...." H.R. REP. No. 96, 68th Cong., 1st Sess. 1 (1924). Lobbyists for the Act appeared to have a more definite conception of the legislation's constitutional basis: "[The Act] rests upon the constitutional provisions by which Congress is authorized to establish and control inferior federal courts." Joint Hearings, supra note 21, at 37. Contra, Committee on Commerce, supra note 21, at 154-55. Congressional confusion may have been induced by the fact that arbitration was considered by the Supreme Court to be a "renuedy," rather than purely a procedural device. See Marine Transit Corp. v. Dreyfus, 284 U.S. 263, 277-79 (1932); Red Cross Line v. Atlantic Fruit Co., 264 U.S. 109, 123-24 (1924); Sturges \& Murphy, 
In Erie Railroad Company v. Tompkins ${ }^{33}$ the Supreme Court held that, absent a preemptive federal statute, state statutory and decisional law must govern federal diversity cases. ${ }^{34}$ The Court indicated that defendants unable to remove to the federal system to contest a state substantive right were denied equal protection of the laws, since they were subject to varying judicial interpretations of the state claim depending upon whether a state or federal forum was selected by their adversary as most favorable to the latter's cause of action. ${ }^{35}$ To neutralize the adversary's advantage, the

supra note 24, at 590-93. Labeling arbitration as remedial suggested that the Act possessed significant substantive characteristics. A court might find that arbitration was "substance" and not "procedure," thus invalidating the Act as an exercise of the article III regulatory power. See Bernhardt v. Polygraphic Co., 350 U.S. 198, 202 (1956); notes 42-46 infra and accompanying text. Indeed, one commentator has suggested that the "procedural" classification was used to gloss over judicial antagonism toward arbitration. Heilman, Arbitration Agreements and the Conflect of Laws, 38 YALE L.J. 617, 648-49 (1929). See notes 9 \& 21 supra and accompanying text. While the Act could easily be,justified today as an exercise of the commerce power, as was done in Prima, 388 U.S. at 405, the 68th Congress apparently did not wish to rest the Act on this constitutional basis alone. This reticence is understandable since, at that time, legislative power under: the commerce clause was still ill-defined. Compare Carter v. Carter Coal Co., 298 U. S. 238 (1936); Umited States v. Butler, 297 U. S. 1 (1936), and Hammer v. Dagenhart, 247 U.S. 251 (1918), with NLRB v. Jones \& Laughlin Steel Corp., 301 U.S. 1 (1937); United States v. Darby, 312 U.S. 100 (1941); Wickard v. Filburn, 317 U.S. 111 (1942), and Katzenbach v. McClung, 379 U.S. 294 (1964).

33304 U.S. 64 (1938).

${ }^{34} I d$. at 78. Prior to Erie the federal uniformity concept of Swift v. Tyson, 41 U.S. (16 Pet.) 1 (1842), was controlling. In interpreting the Federal Judiciary Act of 1789 , ch. $20, \S 34,1$ Stat. 92 (now 28 U.S.C. $\$ 1652$ (1964)), Swift had required the federal courts, in the absence of apphicable federal statutes, to adhere to state statutory but not state decisional law. Thus, the federal courts were to looki to federal precedent and the "federal common law" when litigating a state-created cause of action. See note 35 infra. For modern references to "federal common law" see notes 54 and 113 infra.

35 304 U.S. at 74-77. Erie actually raised three constitutional grounds for overruling Swift $v$. Tyson. See note 34 supra. In addition to demal of equal protection, the Swift rule was thought to be contrary to: (1) the separation of power within the federal government in that it ascribed a legislative function to the judiciary in violation of article I of the Constitution; and (2) the separation of federal-state power as dictated by the tenth amendment. 304 U.S. at 74-80. Erie has served as the focal point for a plethora of commentary. See, e.g., Clark, State Law in the Federal Courts: The Brooding Omnipresence of Erie v. Tompkins, 55 YALE L. J. 267 (1946); Friendly, In Praise of Erie-and of the New Federal Common Law, 39 N.Y.U.L. REv. 383 (1964); Hart, The Relations Between State and Federal Law, 54 ColuM. L. REv. 489 (1954); Hill, The Erie Doctrine and the Constitution, 53 Nw. U.L. REv. 427 (1958); Jackson, "The Rise and Fall of Swift v. Tyson," 24 A.B.A.J. 609 (1938); Keeffe, Gilhooley, Bailey \& Day, Weary Erie, 34 CORNELL L.Q. 494 (1949); Kochery, The Enforcement of Arbitration Agreements in the Federal Courts: Erie v. Tompkins, 39 CoRNELL L.Q. 74 (1953); Kurland, Mr. Justice Frankfurter, The Supreme Court and the Erie Doctrine in Diversity Cases, 67 YALE L.J. 187 (1957); Stason, Choice of Law Within the 
majority instated the law of the forum as supreme in matters of "procedure," and the law of the state as preeminent in inatters of "substance." "36 In attempting to unravel the protean substance-procedure dichotomy of Erie, the Supreme Court in Guaranty Trust Company $v$. York ${ }^{37}$. extrapolated a mechanical "outcome-determinative" test." The Guaranty Court encouraged the judiciary to ignore the state or federal policy being fostered by the granting or withholding of a procedural remedy, in order to assure that the outcome of the dispute be identical in either judicial system. ${ }^{39}$ Thus, in attempting to make the local federal court "only another court of the State" in diversity cases, a federal procedure was to be deemed "substantive" for purposes of Erie if it substantially affected the outcome of the state-created claim. ${ }^{40}$ Since numerous states were opposed to arbitration, 41 invocation of the "outcome-determinative" standard seemingly precluded enforcement of the Arbitration Act in a federal diversity case.

This assumption was borne out in Bernhardt v. Polygraphic Company Of America. ${ }^{42}$ In Bernhardt the Supreme Court held that the "procedural"

Federal System: Erie Versus Hanna, 52 CoRNeLL L.Q. 377 (1967). See generally 2

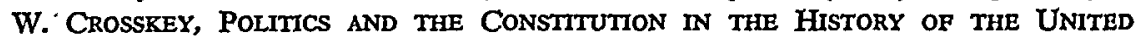
States 912-20 (1953); J. Moore, Commentary on the United States Judicial. Code 315-59 (1949); C. Wright, Federal Courts $\$ \$$ 54-60 (1963).

36304 U.S. at 78 (by implication); see C. WRIGHT, supra note 35, \$§ 54-60; Clark, supra note 35; cf. Angel v. Bullington, 330 U.S. 183, 191-92 (1947).

37326 U.S. 99 (1945).

${ }^{38} I d$. at 109. Subsequent decisions have abandoned the Guaranty Trust test where special circumstances warranted. In Byrd v. Blue Ridge Rural Elec. Cooperative, Inc., 356 U.S. 525, 538 (1958), the Supreme Court refused to apply a state workmen's compensation act in a diversity case, asserting that the "outcome" test was inapplicable where it led to the nullification of a basic federal right such as trial by jury. See Merrigan, Erie to York to Ragan-A Triple Play on the Federal Rules, 3 VAND. L. REv. 711 (1950); Stason, supra note 35, at 392-94. Similarly, in Hanna v. Plumer, 380 U.S. 460, 473 (1965), the Supreme Court held that the Guaranty Trust test did not apply where the Federal Rules of Civil Procedure were in conflict with a state policy. See Stason, supra note 35, at 398-404; Comment, Hanna v. Plumer: An Expanded Concept of Federal Common Law-A Requiem for Erie?, 1966 DUxE L.J. 142; Note, The Operation of Federalism in Diversity: Erie's Constitutional Basis, 40 IND. L.J. 512, 539-41 (1965).

so See 1A J. Moore, Federal Practice II 0.304 (2d ed. 1965).

40326 U.S. at 109.

\&1 See notes 9 \& 21 supra and accompanying text.

42350 U.S. 198 (1956). In Bernhardt the plaintiff brought suit in a Vermont state court for damages resulting from his discharge under an intrastate employment contract. The einployer removed to a federal district court on diversity grounds. Taking advantage of a broad arbitration clause in the employment contract, the plaintiff moved for a stay of court proceedings pending arbitration under $\$ 3$ of the Arbitration Act. The Second Circuit reversed the lower court's denial of a stay, holding that even if the contract in question was not interstate in claracter, and thus not within the ambit of $\$ 2$ of the 
terms of the Act must be read in conjunction with sections 1 and 2, which "define the field in which Congress was legislating." 43 Consequently, the statute was interpreted as not encompassing the intrastate contract involved in that cáse. ${ }^{44}$ Moreover, the Bernhardt Court declared that arbitration could no longer be classified as procedural, because "[it] substantially affects the cause of action created by the State." 45 Thus, the "procedural" remedies of the Act could not be applied as an exercise of the article III power since such an application would render the Act unconstitutional under the Erie-Guaranty Trust doctrine by substituting a federal "outcome" for a contrary state result upon a state cause of action. ${ }^{46}$

After Bernhardt circuit courts disagreed as to whether state or federal law should govern the disposition of a diversity case involving an arbitration agreement within a contract evidencing a transaction in interstate commerce, and thus within the ambit of the Arbitration Act.47 In the leading case of Robert Lawrence Company v. Devonshire Fabrics, Incorporated, ${ }^{48}$ the defendant sought a section 3 stay of the plaintiff's action for fraud in the inducement of an interstate sales contract. In deciding whether the validity of the primary contract was to be determined by the federal court or the arbiter, the Second Circuit interpreted the arbitration clause agreed upon by the parties in terms of section 2 of the Act. ${ }^{49}$ Since

Act, $\$ 3$ of the Act nevertheless applied as procedural law of the forum. Bernhardt $v$. Polygraphic Co. of America, 218 F.2d 948, 951 (2d Cir. 1955).

${ }^{43} 350$ U.S. at 201.

${ }^{44}$ Id. at 200-01. The Court, therefore, did not need to decide whether the contract in Bernhardt would have been excluded under the last clause in $\$ 1$ of the Arbitration Act, which exempts from the Act "contracts of employment of 'seamen, railroad employees, and any other class of workers engaged in foreign or interstate commerce." 9 U.S.C. $\S 1$ (1964); see 350 U.S. at 201, n.3; note 23 supra. Had the Court assumed that $\S 3$ was singly procedural and granted the motion to stay the state cause of action, the outcome would have been substantially different from that of the state court. Under the applicable Vermont law, arbitration agreenents were not enforceable and the ultimate resolution of contractual validity would have been reached by a court and not by an arbiter. 350 U.S. at 204-05, citing Mead v. Owen, 83 Vt. 132, 135, 74 A. 1058, 1059 (1910). See notes 22-23 \& 26 supra.

45350 U.S. at 203.

${ }^{40} \mathrm{Id}$. at 202, 208 (Frankfurter, J., concurring); see Prima Paint Corp. v. Flood \& Conklin Mfg. Co., 388 U. S. 395, 411, 416, 420 (1967) (Black, J., dissenting); cf. Note, 69 YALE L.J. 847, 848 (1960).

${ }^{47}$ Compare Robert Lawrence Co. v. Devonshire Fabrics, Inc., 271 F.2d 402 (2d Cir. 1959), with Lummus Co. v. Commonwealth Oil Ref. Co., 280 F.2d 915 (1st Cir.), cert. denied, 364 U.S. 911 (1960).

18271 F. 2d 402 (2d Cir. 1959), noted in 60 ColUM. L. REv. 227 (1960); 45 CoRNell L. Q. 795 (1960); 73 HARV. L. REv. 1382 (1960); 46 IowA L. REv. 167 (1960); 12 Stan. L. REv, 831 (1960); 108 U. PA. L. Rev. 915 (1960); and 46 VA. L. REV. 340 (1960).

${ }^{40} 271$ F.2d at 409-12. Previous Second Circuit opinions had indicated that the illegality of a portion of a contract did not nullify an agreement to arbitrate, see, e.g., 
that section validated only arbitration provisions, and not the entire contract, the circuit court ruled that the arbitrators should decide the validity of the container contract. ${ }^{50}$ As the plaintiff in Lawrence had failed to allege fraudulent inducement of the arbitration agreement itself, a stay of legal proceedings pending arbitration was granted.51 Furthermore, by locating the constitutional warrant for section 2 in the commerce clause, the Lawrence court was able to declare that section 2 and the "separability doctrine" were controlling in all diversity cases as "national substantive law,"52 adding by way of dictum that both were "equally applicable in state or federal courts." 53 In this manner the Second Circuit avoided the

Wilko v. Swan, 201 F.2d 439 (2d Cir.), rev'd on other grounds, 346 U.S. 427 (1953), and that an alleged breach of the contract did not preclude arbitration, Kulukundis Shipping Co. v. Amtorg Trading Corp., 126 F.2d 978 (2d Cir. 1942). Although the posture of New York law is unclear, apparently the courts of that state, rather than an arbitrator, determine fraud in the inception of a contract. In view of the decision in Prima it was unnecessary for the Court to make an actual finding as to the applicable New York law. 388 U.S. at 400, n.3. However, in Lawrence the Second Circuit concluded by way of dictum that a contrary result would have been reached had New York law been applied rather than the federal "separability doctrine." 271 F.2d at 412; see Wrap-Vertiser Corp. v. Plotnick, 3 N.Y.2d 17, 143 N.E.2d 366, 163 N.Y.S.2d 639 (1957). Compare Exercycle Corp. v. Maratta, 9 N.Y.2d 329, 174 N.E.2d 463, 214 N.Y.S.2d 353 (1961), and Amerotron Corp. v. Maxwell Shapiro Woolen Co., 3 App. Div. 2d 889, 162 N.Y.S.2d 214 (1957), aff'd, 4 N.Y.2d 722, 148 N.E.2d 319, 171 N.Y.S.2d 111, (1958), with Fabrex Corp. v. Winard Sales Co., 23 Misc. 2d 26, 200 N.Y.S.2d 278 (Sup. Ct. 1960). But cf. Lummus Co. v. Commonwealth Oil Ref. Co., 280 F.2d 915, 923-27 (1st Cir.), cert. denied, 364 U.S. 911 (1960).

${ }^{50} 271$ F.2d at 411 ; see 9 U.S.C. $\S 2$ (1964); note 22 supra. See text following note 62 infra.

51271 F.2d at 413.

62 Id. at 409; accord, Monte v. Southern Delaware County Authority, 321 F.2d 870, 873-74 (3d Cir. 1963); Electronic \& Missile Facilities, Inc. v. United States, 306 F.2d 554, 558 (5th Cir. 1962), rev'd on other grounds sub nom. Moseley v. Electronic \& Missile Facilities, Inc., 374 U.S. 167 (1963); Standard Magnesium Corp. v. Fuchs, 251 F.2d 455, 457-58 (10th Cir. 1957). See also Brief for Respondent at 16, Prima Paint Corp. v. Flood \& Conklin Mfg. Co., 388 U.S. 395 (1967).

${ }^{53} 271$ F.2d at 407 (emphasis added). Subsequent cases in the Second Circuit have reaffirmed the suggestion in Lawrence that the Arbitration Act and the "separability doctrine" were national substantive law, equally applicable in the state courts as in the federal judiciary. See Marcy Lee Mfg. Co. v. Cortley Fabrics Co., 354 F.2d 42 (2d Cir. 1965); World Brilliance Corp. v. Bethlehein Steel Co., 342 F.2d 362 (2d Cir. 1965); El Hoss Eng'r \& Transp. Co. v. American Independent Oil Co., 289 F.2d 346 (2d Cir.), cert. denied, 368 U.S. 837 (1961); In re Kinoshita \& Co., 287 F.2d 951 (2d Cir. 1961); Metro Indus. Painting Corp. v. Terminal Constr. Co., 287 F.2d 382 (2d Cir.); cert. denied, 368 U.S. 817 (1961); Amicizia Societa Navegazione v. Chilean Nitrate \& Iodine Sales Corp., 274 F.2d 805 (2d Cir.), cert. denied, 363 U.S. 843 (1960). See also Brief for Respondent at 16 \& n.*, Prima Paint Corp. v. Flood \& Conklin Mfg. Co., 388 U.S. 395 (1967). Commentators have generally favored the "separability doctrinc." See Baum \& Pressman, The Enforcement of Commercial Arbitration Agreements in 
emasculation of the Act which Bernhardt seemed to require..$^{54}$

Affirming defendant Flood \& Conklin's motion to stay the action for recission pending arbitration, the Prima Court first established that the arbitration clause in question was part of a "contract evidencing a transaction involving commerce" as contemplated by sections 1 and 2 of the Arbitration Act.55 Apparently, the consulting agreement, which included the

the Federal Courts (pt. 2), 8 N.Y.U.L.Q. REv. 428, 439 (1931); Nussbaum, The "Separability Doctrine" in American and Foreign Arbitration, 17 N.Y.U.L.Q. REv. 609 (1940); Comment, Judicial Control of the Arbitrator's Jurisdiction: A Changing Attitude, 58 Nw. U.L. Rev. 521, 522-32 (1963); Comment, Fraudulent Inducement as a Defense to the Enforcement of Arbitration Contracts, 36 YALE L.J. 866 (1927). For a criticism of the "separability doctrine" see A. Corrnn, 6A Contracts \& 1444, at 449-50 (1962). One writer has suggested that the doctrine may be of common law origin. See Parsell, Arbitration of Fraud in the Inducement of a Contract. 12 CoRNELL L.Q. 351, 353-54 (1927).

${ }^{54}$ See note 46 supra and accompanying text. Viewed as substantive law, the Arbitration Act would always govern an arbitration agreement in a contract involving imterstate commerce. The Lawrence court also made clear that the federal judiciary was to develop the Act interstitially, disclosing the "federal law." 271 F.2d at 409. See note 113 infra. The Lawrence approach neatly avoided any possible equal protection problem reminiscent of Erie since federal law applied in all diversity cases, whether brought in state or federal courts, and the commerce clause provided a federal right, thus removing one of the underpinnings of Erie-federal court treatment of a state cause of action. See text following note 84 infra. The main objection to this position lay in the absence of congressional intent to extend the Act to the states. See note 118 infra and accompanying text. Perhaps for this reason the First Circuit, in Lummus Co. v. Commonwealth Oil Ref. Co., 280 F.2d 915 (1st Cir.), cert. denied, 364 U.S. 911 (1960), refused to apply the Arbitration Act to the states in a diversity case. In Lummus the plaintiff instituted an action in the district of Puerto Rico for rescission of a'construction contract, and the defendant moved in a New York state court to compel arbitration. The plaintiff removed to a New York federal district court on the basis of diversity, obtaining a preliminary injunction against 'arbitration in New York. On appeal, the circuit court applied New York law in vacating the imjunction. Dismissing the:plaintiff's action as a disguised attempt to avoid arbitration, $i d$. at 930 , the court, in dictum, eschewed the "separability doctrine" advocated in Lawrence. Instead, the First Circuit noted that the parties' contacts with New York would have dictated application of New York law. Id. at $923-24$.

The Lummus choice of laws approach may not be objectionable in terms of the equal protection question raised by Erie, see notes 33-36 supra and accompanying text, since, theoretically, whenever the state has a legitimate interest in the contract in dispute, the same law would apply in both the state courts and federal courts within that state. However, the conflicts analysis virtually nullifies the provisions of the Arbitration Act in diversity cases because state interest in the enforcement of contracts of any type is probably equal or superior to the federal interest in promoting arbitration. Lummus, then, merely effectuated in a novel form the emasculation of the Act seemingly permitted by Bernhardt. Thus, while Lawrence required the judiciary to indulge in what can be reasonably described as "judicial legislation," sce notes 118-20 infra and accompanying text, Lummus significantly limited a valid federal statute.

${ }^{\text {Es }} 388$ U.S. at 400-01; see 9 U.S.C. \$§ 1-2 (1964). 
arbitration clause, did not itself encompass such a transaction. While in addition to consultation the agreement provided for a transfer of a list of interstate customers and a covenant not to compete, it did not embrace an actual "transaction involving commerce" in the same manner as the original sales contract ${ }^{56}$ To bring the consulting provisions within the Act, the Court noted that the agreement was designed to effectuate the transfer of ownership and was thus an adjunct to the sales contract.57

The facts of Prima substantiate the Court's reasoning that the two agreements were "inextricably tied," for they jointly provided for the transfer and continued operation of the interstate paint business..$^{58}$

${ }^{56} 388$ U.S. at 401 \& n. 6 . See note 11 supra.

${ }^{z 7} 388$ U.S. at 401 . It may have been unnecessary to read the consulting agreement into the sales contract in order to bring the arbitration clause within the $\$ 2$ prerequisite of a "contract evidencing a transaction involving commerce," 9 U.S.C. $\$ 2$ (1964), since the lists of Flood \& Conklin's interstate customers were appended to the consulting agreement. But see text following note 60 infra. Yet, the consulting agreement was primarily a personal employment contract between Prima Paint and Flood \& Conklin's chairman of the board. 388 U.S. at 397. Since Bernhardt involved an employment contract held to be beyond the scope of the Arbitration Act, the Prima Court apparently felt constrained to seek a basis other than that presented by the customer lists for bringing the consulting agreement within the Act, even though Bernhardt was decided on the basis of the intrastate character of that employment contract and thus would not appear to present a bindimg precedent. See note 42 supra and text preceding note 47 supra.

The dissenters argued that the "commerce" of $\$ 2$ encompassed only the interstate transfer of physical goods between merchants. 388 U.S. at 409-10 \& nn.2-3 (Black, Douglas, Stewart, JJ., dissenting). Contra, Joint Hearings, supra note 21, at 39; Committee on Commerce, supra note 21, at 154-55, citing American Express Co. v. Iowa, 196 U.S. 133, 143 (1905). However, the only evidence set forth by the dissenters to substantiate this limitation was (1) the fact that the sponsors of the legislation were merchants, 388 U.S. at 409, n.2 (see representative list of sponsors of the Arbitration Act in Brief for American Arbitration Ass'n as Amicus Curiae at Appendix, Prima Paint Corp. v. Flood \& Conklin Mfg. Co., 388 U.S. 395 (1967), and (2) the use of the phrase "involving commerce" rather than the words "affecting commerce" which are employed in some other commerce clause-legislation, such as the Federal Employers' Liability Act, 45 U.S.C. $\$ 51$ (1964). 388 U.S. at 410, n.3. The legislative history of the Arbitration Act does not reveal any congressional intention to restrict the statute to goods between merchants. Cf. Joint Hearings, supra note 21, at 7, 16, 27-28. Moreover, $\S 1$ of the Act defines "commerce" in strict commerce clause language: "commerce among the several States or with foreign nations." The section would thus appear to be an absolute invocation of the commerce power. See S. REP. No. 536, 68th Cong., 1st Sess. 1 (1924); 65 CoNG. REC. 1931 (1924) (remarks of Representative Graham). In addition, $\$ 1$ does exclude some types of interstate contracts. See note 23 supra. Thus, if Congress meant to limit the Act as the dissenters suggest, it would seem likely that the section would have been made similarly explicit.

${ }^{58}$ The president of Prima Paint admitted in an affidavit that the consulting agreement was "intended" for the "orderly transfer of the assets." 388 U.S. at 401, n.6. See note 11 supra. Arguably, the short period of three weeks between the signing of the two 
Nonetheless, the Court's language may be unduly broad. Had the consulting agreement been entered into six months instead of three weeks after the sales contract, the former presumably would still have been made for the purpose of proinoting the company's "continuing operations." 59 In such a situation, however, grafting the arbitration provision onto the initial sales contract would arguably be an unwarranted extension of the parties' probable intent to arbitrate only those disputes arising under the consulting contract.60 Nevertheless, the Court's compulsion to annex the consulting agreement to the sales contract may have revealed the outside limitations on the scope of the act. ${ }^{61}$

Having established the federal Act's applicability to the arbitration provision in Prima, the majority considered whether the Act prescribed arbitral or judicial determination of Prima's claim that the consulting

contracts suggests that the contracts were related, particularly in light of the nature of each agreement-one provided for the transfer' of assets, and the other for the more profitable use of those assets by the buyer. Indeed, the management experience of Flood \& Conklin's board chairman would be of questionable value if there were no actual sale of Flood \& Conklin's facilities to Prima. However, a party may be more willing to agree to arbitrate disputes arising out of a contract for advice and consultation than those resulting from the transfer of a business, since the former involves a promise of personal service and may not be as susceptible to satisfactory judicial enforcement as is an executory contract for the sale of a business.

${ }^{60}$ See 388 U.S. at 401.

${ }^{\infty}$ In Prima the parties may have felt that a clash of opinion might be generated by the consulting agreement and that arbitration should be provided as a means of amicably resolving any differences. Moreover, the complaint only alleged fraud in the making of the consulting agreement, which might suggest that the parties didl not intend the arbitration agreement to cover the sales contract. 388 U.S. at $398 \&$ n.2. See note 13 supra. Thus, it wonld appear that the arbitration provisions were only designed to apply to the consnlting agreenent. Yet the Court omits any discussion of the parties' intent as to the scope 'of arbitration under the arbitration clause. This seems inconsistent with the Court's treatment of contractual intent in its discussion of the "separability doctrine." 388 U.S. at 402; see note 67 infra. In presenting the elements of that doctrine, the Prima Court agreed with the Second Circuit in Lawrence, 271 F.2d at 410-12, that arbitration clauses were severable from the container contract "except where the parties otherwise intend." 388 U.S. at $402,406$.

o1 See also Wilko v. Swan, 346 U.S. 427, 430 (1953); Metro Indus. Painting Corp. v. Terminal Constr. Co., 287 F.2d 382, 384 (2d Cir.), cert. denied, 368 U.S. 817 (1961). The majority opinion implied that the conjunction of a multi-state customer list, a provision for advice and consultation, and a covenant not to compete is insufficient to satisfy the $\S 2$ requirement that an enforceable arbitration clause be part of a contract evidencing a transaction involving commerce. 9 U.S.C. $§ 2$ (1964); note 22 supra. Conversely, the majority rejected the dissent's position that the Arbitration Act applies only to "contracts between merchants for the imterstate shipinent of goods." 388 U. S. at 401 n.7, 409-10 (Black, J., dissenting); see note 57 supra. As a result the Prima Court apparently defined a "transaction involving commerce" as an agreement which has an immediate effect upon interstate commerce. 
agreement had been fraudulently induced. ${ }^{62}$ In resolving the same question in Lawrence, the Second Circuit had constructed the "separability doctrine" from the "substantive" section 2 mandate that arbitration agreements are "valid, irrevocable, and enforceable." 63 However, the Prima Court focused upon the "procedural" language of section $4 .{ }^{64}$ Under the latter provision, a district court is to compel arbitration once "satisfied that the making of the agreement for arbitration or the failure to comply therewith is not in issue...."65 Specifically limiting the holding to cases "brought in a federal court involving maritime contracts or those evidencing transactions in "commerce," 66 the Supreme Court ruled that an allegation of fraud in the inducement of the contract generally did not challenge the validity of the arbitration agreement itself. Conscquently, under section 4 , validity of the contract was to be evaluated by the arbitrator. ${ }^{67}$ Additionally, the Court

\footnotetext{
62388 U.S. at $402-04$.

${ }^{63} 271$ F.2d at 409-11. See note 22 supra and accompanying text.

64388 U.S. at 403-04. See note 26 supra and accompanying text.

659 U.S.C. $\$ 4$ (1964) (emphasis added); 388 U.S. at 403.

${ }^{68} 388$ U.S. at 403.

${ }^{67} I d$. at 403-04, 406-07. The majority did not construe the clause of $\$ 4$ which
} directs a federal court to compel arbitration "in accordance with the terms of the agrecment." 9 U.S.C. $\$ 4$ (1964). See generally W. STURGES, supra note 28, at 929-30. Parties agreeing to arbitrate. a dispute arising out of the transfer of an interstate business arguably do not anticipate the extension of their right to a judicial determination of the validity of the sales contract itself. Since arbitration proceedings are generally designed to capitalize on business expertise for the resolution of "teehnical," rather than "legal," controversies, 388 U.S. at 407-08; see Baum \& Pressman, supra note 21, at 249-50; Cohen \& Dayton, supra note 28, at 281; Coulson, Tailoring Arbitration to Business Needs, 19 BUs. LAWYer 1037, 1041-43, 1045, 1050 (1964); Coulson, ArbitrationPositive Experiments in Modern Justice, 50 JUDiCATURe 125, 127 (1966), the actual intent to arbitrate the legal question of contract validity is likely to be non-existent. Thus, arbitration in this instance would not be "in accordance with the terms of the agreement," since it would violate an implied understanding that questions of contractual validity be judicially determined. Moreover, if the arbitrator subsequently decides that the primary contract is valid, a court is presented with the anomaly of having enforced one clause to declare the invalidity of the entire agreement. 388 U.S. at 425 (Black, J., dissenting).

Perhaps the strongest argument against the "separability doctrine" is the lack of procedural safeguards for the resolution of essentially "legal" issues. Since arbitrators are usually non-judicial officers chosen for their practical expertise, their primary efforts are directed toward compromising the interests of the parties and not to observing the precedential impact of previous determinations. See Comment, Judicial Review of Arbitration: The Role of Public Policy, 58 Nw. U.I. REv. 545, 547 (1963). In addition, teehnical expertise would seem of limited value in adjudicating legal issues, especially since procedural devices such as rules of evidence, burden of proof, and res judicata are not generally incorporated into the arbitration proceedings. See Kochery, supra note 35, at 93, n.89; cf. Nussbaum, supra note 53, at 614-15. As was stated by the dissent in Prima: "[T] he arbitrators the Court holds are to adjudicate the legal validity of the contract need not even be lawyers, and in all probability will be nonlawyers, wholly 
gave implicit approval to the Lawrence dictum that federal law is to be employed in the interpretation and construction of the arbitration agreements as well as the determination of their validity. ${ }^{68}$ Hence, the view

unqualified to decide legal issues, and ... not bound to do so... . [The] Act's language and history show that both Congress and the framers of the Act [emphasized] ... that nonlawyers designated to in . . arbitrate factual controversies arising out of valid contracts would not trespass upon the courts' prerogative to decide the legal question of whether any legal contract exists upon which to base an arbitration." 388 U.S. at 407.08 (Black, J., dissenting); Compare Cohen \& Dayton, supra note 28, at 281, with Coulson, Prima Paint: An Arbitration Milestone, 23 BUS. LAWYER 241, 246 (1967).

One commentator maintains that the concept of severability conflicts with the "integrated commercial transaction" approach of the Uniform Commercial Code. Colhins, Arbitration and the Uniform Commercial Code, 21 ARB. J. 193, 194-95, 203-06, 213-14 (1966). But see Bernstein, The Impact of the Uniform Commercial Code Upon Arbitration: Revolutionary Overthrow or Peaceful Coexistence?, 22 ARB. J. 65 (1967).

${ }^{68}$ The majority held that the arbitration provision involved in the present case was easily broad enough to encompass Prima's claim of fraud. 388 U.S. at 406. Since New York law requires the opposite conclusion, the Court must have applied federal law in its interpretation. See note 49 supra.

Locating the separability doctrine in $\$ 4$ of the Act created textual difficulties for the Court. Section 4 provides a remedy for the party aggrieved by a failurel to arbitrate, giving a federal court with jurisdiction the power to compel arbitration unless the making of the arbitration agreement or the failure to comply with it are in issue. Thus, $\$ 4$ limits judicial consideration of contractual validity to those instances when the legitimacy of the arbitration clause or the fact of performance under it is questioned. Section 3, on the other hand, applies where, as in Prima, a suit has been instituted and the defending party seeks a stay of judicial proceedings for the purpose of arbitrating. Facially, $\$ 3$ requires that a stay be granted unless the issue in the suit was not intended to be arbitrable under the parties' agreement. See notes 26-27 supra and accompanying text. Apparently believing that a $\S 3$ test of intention to arbitrate would mandate judicial jconsideration of all issues where fraud in the inducement of a contract is alleged while a' $\$ 4$ separability doctrine would not, the Court read the separability doctrine of $\S 4$ into $\S 3$ in order to avoid a potential race to the courthouse whenever the validity of the entire contract is in question. 388 U.S. at 403-04. Why this circuitous route was necessary is not apparent. Granting that $\$ 4$ mandates severable treatinent of an arbitration clause, this merely raises the further question whether a general allegation of fraud in the inducement of a contract puts the making of the arbitration agreement in issue. 388 U.S. at 410 (Black, J., dissenting). It is certainly not manifest that the latter question requires a negative answer. It should be noted, however, that the Lawrence court located the source of the separability doctrine in $\$ 2$ of the Act. 271 F.2d at 404-07. The Prima Court apparently grounded the doctrine in $\$ 4$ rather than in $\$ 2$ because the former is more explicit in its treatunent of the arbitration clause as severable from the entire contract. Nonetheless, in a footnote, the Court in Prima implied that the separability doctrine is not inconsistent with, and encompassed by, the "savings clause" of $\$ 2$. 388 U.S. at $404 \&$ n.12. Arguably the separability doctrine is contrary to the policy of the $\$ 2$ savings clause-to make arbitration agreements as enforceable, but not more so, than any other contract. By severing the arbitration clause from the container contract, the Court gives it a sanctity no other term of the contract has. Moreover, such treatment can hardly comport with the commercial understanding of busi- 
of the Lawrence Court that the Act creates a body of federal common law to govern all questions surrounding arbitration appears to have been vindicated in Prima. ${ }^{69}$

nessmen. A party induced to sign - a contract containing a standard form arbitration clause can hardly be deemed to have intended to arbitrate the purely legal question of whether the entire contract is voidable because of fraudulent misrepresentations of solvency by the other party.

Unanswered by Prima is whether state or "federal" law is to be applied in determining the validity of the principal contract whenever it is specifically alleged that the arbitration clause was induced by fraud. The statute itself is ambignous. Section 2 states merely that the guarantees of the Act become inoperative when the arbitration agreement is questioned "upon such grounds as exist at law or in equity for the revocation of any contract." 9 U.S.C. $\$ 2$ (1964) (emphasis added). See note 22 supra. Historically, the law of contraets has developed in state courts; thus, the legal and equitable doctrines such as failure of consideration, fraud, incapacity, and duress would seem to be applicable under § 2. See Committee on Commerce, supra note 21, at 154-55; cf. Friendly, supra note 35 , at 397 . However, since Prima indicates that the Act constitutes a federal right, at least in the federal courts, see 388 U.S. at $400,403,405$, it would seem preferable, for purposes of uniformity, that the federal courts develop "federal law" in this area as was suggested by Lawrence. See Friendly, supra at 408-21; Hill, The LawMaking Power of the Federal Courts: Constitutional Preemption, 67 CoLUM. L. REv. 1024, 1028-30, 1036-42 (1967); notes 53-54 supra \& note 113 infra and accompanying text. But cf. Poor, Arbitration Under the Federal Statute, 36 YALE L.J. 667, 671-72 1927); Sayre, Development of Commercial Arbitration Law, 37 YALE L.J. 595, 616-17 (1928).

Where only limited portions of a contract are arbitrable and the validity of the entire contract is challenged, additional problems are created. $\mathbf{A}$ decision by an arbitrator is binding as to those items properly submitted to his consideration in conformity with the arbitration agreement, unless the award is inodified upon one of the statutory grounds. See generally W. STuRGES, supra note 28, $\$ 225-36,289-307$. See also note 28 supra. Presumably, however, the arbitrator's determination of contractual validity would not be final as to those contract provisions excluded from arbitral consideration under the agreement. Thus, in a judicial proceeding in which a non-arbitrable provision is subsequently challenged, a court might be presented with the possibility of declaring a contract invalid even though portions of it had previously been adjudged enforecable by an arbitrator. The real difficulty arises when enforcement of an award is sought prior to a judicial determination of the contract's validity. A party receiving an adverse decree from an arbitrator could effectively delay enforcement by challenging the contract's validity in a court proceeding, thereby subverting the goals of arbitration. Sce note 21 supra.

Even where the validity of the arbitration clause is not questioned, broad arbitration agreements similar to that in Prima, see note 12 supra, give rise to interpretive problems, since those disputes which are proper subjects for arbitration under a broad agreement have not yet been determined. One federal court has held that an antitrust claim may be arbitrated under such a clause. American Safety Equip. Corp. v. Hickok Mfg. Co., 271 F. Supp. 961 (S.D.N.Y. 1967). But see Farber, The Antitrust Claimant and Compulsory Arbitration Clauses, 28 FED. BAR J. 90 (1968). On appeal, however, the Second Circuit reversed, citing the important public interest in antitrust litigation, and remanded for arbitration of those issues not involving antitrust claims. American Safety Equip. Corp. v. J. P. Magnire \& Co., — F.2d - (2d Cir. 1968).

${ }^{69}$ See note 54 supra. 
Untreated by the Court, however, are several constitutional issues raised by the separability doctrine. Since the size of an arbitrator's fee may depend upon the length of his deliberations, as urged by Mr. Justice Black in his dissent, ${ }^{70}$ it is in an arbitrator's own interest to refuse to find fraud in the making of the arbitration agreement, or in the making of the principal contract, in order to retain jurisdiciton. ${ }^{71}$ Decisions by an official who has a "direct, personal, substantial, pecuniary interest" in the outcome of a proceeding have been overturned by the Supreme Court as a deprivation of the litigant's right to due process. ${ }^{72}$ Arguably, such a rationale would emcompass an arbitrator's interest in an arbitration proceeding since a determination of contract validity seems to promote his pecuniary advantage. ${ }^{33}$ The extent of the arbitrator's remuneration, however, is necessarily contingent upon the existence of a continued controversy, or future controversies, between the parties who sought the arbiter's services, and a decision in favor of contract validity may induce the losing party to settle voluntarily without further arbitration. Thus, the arbiter's interest is not as certain as that of a magistrate who is entitled to a percentage of each fine assessed. In fact, in the majority of instances the arbitrator receives no

${ }^{70} 388$ U.S. at 416 (Black, J., dissenting).

${ }^{71}$ In those instances in which a commercial arbitrator is compensated, fees are computed on a per diem basis- $\$ 100$ per day being the rate suggested by the American Arbitration Association. The Association maintains, however, that the arbitrator is compensated in less than $10 \%$ of non-labor arbitration cases. Coulson, Prima Paint: An Arbitration Milestone, 23 BUS. LAWYER 241, 246 (1967). Several states set arbitral fees by statute. See, e.g., IOWA CODE ANN. $\$ 679.17$ (1950) ( $\$ 2$ per diem); KAN. STat. ANN. \$ 5-213 (1964) (\$1 per diem); Pa. STat. ANN. tit. 5, \& 129 (1963) (\$35 per diem); TENN. CODE ANN. \$ 23-516 (1955) ( $\$ 5$ per diein).

${ }^{2}$ Tumey v. Ohio, 273 U.S. 510, 523 (1927), noted in 40 HARv, L. REv. 1149 (1927), 1 U. CIN. L. Rev. 338 (1927), 13 VA. L. REv. 584 (1927) and 36 YALE L.J. 1171 (1927). Tumey involved a conviction for unlawful possession of liquor. Under state law, money received in payment of a fine was to be divided equally between the state and township treasuries. In the municipality in question, the township's share was to be used to finance enforceinent of the liquor law and to compensate the mayor for hearing 'cases involving infractions of that law. The Supreme Court overturned the conviction rendered by the mayor, reasoning that the latter's pecuniary interest in the outcome violated the defendant's right to due process of law. 273 U.S. at 523, 533, 535; accord, United States v. O'Connor, 291 F.2d 520, 526 (2d Cir. 1961) (receiver appointed as special master); Stockwell v. Township Bd., 22 Mich. 341 (1871). But see Bevan v. Krieger, 289 U.S. 459 (1933) (compensation too remote and judgment subject to de novo judicial review); Dugan v. Ohio, 277 U.S. 61 (1928) (mayor on fixed salary). A most literal application of the Tumey doctrine is demonstrated by' Pearce v. Atwood, 13 Mass. 324 (1816), in which the Massachusetts Supreme Court disallowed an arrest warrant issued by a magistrate because the magistrate was an inhabitant of the town which was to receive any fine assessed undcr the particular offense charged. Said the court: "Any interest ... ., however small, has been held sufficient to reuder a judge incompetent." Id. at 340 .

${ }^{73}$ See note 71 supra and accompanying text. 
compensation regardless of the length of his deliberations. ${ }^{74}$ Moreover, the Arbitration Act provisions allowing judicial reversal of an award for fraud or corruption mitigate the possibility of arbitral bias, ${ }^{75}$ although the judiciary has historically been reluctant to reverse the findings of an arbitrator. ${ }^{76}$ Further, partiality and fraud, while matters of evidence, are difficult of proof.77 Thus, in those instances in which an arbitral fee is affected by a preliminary finding by an arbitrator as to the validity of a contract, a more extensive judicial inquiry into the actual arbitration proceedings would seem desirable whenever review is sought.78

The format attendant arbitration, in combination with the separability doctrine, presents an additional constitutional complication. The seventh amendinent extends the right to jury trial to all suits at common law. Since fraud in the inducement of a contract was actionable at common law, 79 the parties in Prima would normally be entitled to a jury trial of Prima's action for rescission under the dictates of the seventh amendment. ${ }^{80}$ Arbitration does not qualify as a jury trial since it is a non-judicial proceeding conducted by a selected individual or individuals, and not a trial before a panel of randomly chosen peers. ${ }^{81}$ Consequently, unless it can be said that the right to jury trial had been waived, ${ }^{82}$ the Prima decision would seem to deny the seventh amendment guarantee by submitting the question of the validity of the consulting agreement to an arbitrator. If entered into willingly and with full knowledge of its ramifications, the arbitration agreement could be viewed as such a waiver. ${ }^{83}$ As a practical matter, however, parties to an arbitration contract are not likely to anticipate the need for either an arbitral or judicial determination of contractual validity,

74 Id.

${ }^{75}$ See 9 U.S.C. $\$ \S 10-11$ (1964); note 28 supra and accompanying text.

${ }^{76}$ W. Sturges, Commercial ARbitrations ANd Awards $\$ 235$, at $613 \& \mathrm{n} .259$ (1930); see Glick, Bias, Fraud, Misconduct and Partiality of the Arbitrator, 22 ARB. J. 161 (1967); Comment, Judicial Review of Arbitration: The Role of Public Policy, 58 Nw. U.L. REv. 545, 546 (1963). See also Poor, supra note 68, at 674-76.

77 See W. STuRges, supra note 76, $\$ \$ 364-67$.

78 The Arbitration Act provides for judicial review of an arbitral award in the federal district court for the district in which the award was made. 9 U.S.C. $5510-11$ (1964). Review may be requested by either party to the award within the confines set forth in $\$ \$ 10-11$ of the Act. See note 28 supra. One writer has suggested that the Uniform Commercial Code provides a greater opportunity for state court review of an arbitrator's award than do the various state arbitration statutes. Collins, supra note 67, at 211-14.

${ }^{70}$ E.g., Lang v. Giraudo, 311 Mass. 132, 40 N.E.2d 707 (1942); American Laundry Mach. Co. y. Skinner, 225 N.C. 285, 34 S.E.2d 190 (1945).

80388 U.S. at 412-15 (Black, J., dissenting).

${ }^{81}$ See note 67 supra.

82388 U.S. at $413-14 \&$ n.10 (Black, J., dissenting).

${ }^{83}$ Id.; cf. In re Bendix Aviation Corp., 190 Misc. 889, 75 N.Y.S.2d 899 (Sup. Ct. 1947). 
and the contract would not be an expression of their intent on this matter. To find a valid waiver, therefore, evidence of an affirmative disclaimer would appear indispensable. For this reason, the separability doctrine, at least as applied retrospectively to the parties in Prima, would seem a harsh procedure. Yet, by requiring the parties to enumerate specifically those issues in the contract which are to be juridically considered in order to overcome the presumption of arbitral jurisdiction, the Prima Court is giving effect to the congressional policy in favor of arbitration. ${ }^{84}$

In order to apply the Arbitration Act and the separability doctrine to the facts in Prima, the Supreme Court liad to determine whether, as Bernhardt intimated, state law was controlling by virtue of Erie and Guaranty Trust. 85 Contending that Prima was not a "simple" diversity case, the majority expressly denied that either the substantive-procedural dualisin of Erie or the "outcome-determinative" test of Guaranty Trust were relevant. Instead, the Court viewed the issue to be "whether Congress may prescribe how federal courts are to conduct themselves with respect to subject matter over which Congress plainly has power to legislate." 86 So framed, the question dictated an affirmative answer. The Court completed its analysis by declaring the Act to be a legitimate exercise of the federal commerce power, regulating federal court treatment of a federal claim. 87

In its establishment of the substantive rules of the Act as giving rise to a federal right, Prima is entirely consistent with Bernhardt, for the latter questioned the Arbitration Act's constitutionality in terms of federal court treatment of a state-created right and did not rule upon the Act's constitutional antecedents. ${ }^{88}$ However, by speaking only of federal court enforcenent of the Act and the separability doctrine, ${ }^{89}$ the Supreme Court may liave exposed the Act to an equal protection attack ${ }^{90}$ by a party not

84 388 U.S. at 406. See notes 106-13 infra and accompanying text.

${ }^{85}$ See text accompanying notes 33-41 supra \& notes 3-4 supra.

80388 U.S. at 405.

${ }^{87} \mathrm{Id}$. at 405-06. While evidence of congressional reliance npon the commerce clause as the basis for the Act is not as substantial as the Prima opinion would indicate, the wording of $\S \S 1$ and 2 tends to support the commerce clause antecedent. See notes 24 \& 32 supra and accompanying text.

${ }^{83}$ See notes $45-46$ supra and accoinpanying text.

80388 U.S. at 403-06.

${ }^{80}$ See id. at 424-25 (Black, J., dissenting). The factual situation of Prima does not present the equal protection objection in its clearest form, for the Court did not have to deal with a state court's refusal to apply the Arbitration Act to an interstate arbitration agreement. Since Prima's action for recision was brought in a federal district court on diversity grounds, the Court did not have to consider the propriety of state court adherence to the Act. For this reason, one may read the Court's refusal to adopt the Lawrence rationale that the mandate of $\$ 2$ is binding upon the states as a conscious attempt to limit Prima to its facts. However, the majority's statement that Prima was not a "simple diversity case," id. at 405 , arguably snggests that the Court viewed the 
able to gain access to the federal courts for enforcement of the Act's substantive rules. Not only would removal be unavailable to a resident defendant, ${ }^{91}$ but also original federal actions are subject to the dual jurisdictional requirements set forth in the procedural sections of the Act. ${ }^{92}$ Section 4, for example, states that a party seeking enforcement of an arbitration agreement "nuay petition any United States District Court, which, save for such agreement, would have jurisdiction . . . ."93 Recourse to the federal courts, therefore, is contingent upon the existence of both an arbitration agreement in a contract involving interstate commerce and separate federal question or diversity jurisdictional grounds. ${ }^{94}$ If the Arbitration Act applies only in the federal courts, this double jurisdictional requirement, together with the limitations of the federal removal statute, subjects a resident of a state hostile to arbitration to differing state and federal court treatment of a contract within the purview of the Act. For example, if a claim of fraudulent inducement is brought in a state court, the state court would adjudicate, administering state contract law. The same claim brought in the local federal court would, as a consequence of the "separability doctrine," be determined by an arbiter in compliance with the arbitration agreement. Hence, where a resident is sued in a local state court,

case as without the scope of Erie, and thus saw no need to extend the Act to the states in order to sustain its constitutionality. Yet, in denying the applicability of the ErieGuaranty Trust doctrine because the Act provides a federal cause of action, id. at 404-05, the majority has not dealt with the rationale of Erie that concurrent state and federal court jurisdiction should not give rise to "forum-shopping" and "unconstitutional discrimination." Id. at 424-25 (Black, J., dissenting); see text accompanying notes 88 supra \& 106 infra.

${ }^{01} 28$ U.S.C. $\$ 1441$ (1964). Since the Arbitration Act itself does not grant the federal district courts original jurisdiction, see note 26 supra and text accompanying notes 29 supra \& 92-4 infra, or federal question jurisdiction, see note 96 infra and accompanying text, an action based upon the Act will be removable "only if none of the parties in interest properly joined and served as defendants is a citizen of the State in which such action is brought." 28 U.S.C. \$ 1441 (b) (1964).

${ }^{92}$ See 9 U.S.C. $\$ \$ 3-13$ (1964). See note 26 supra and text accompanying note 29 supra.

${ }_{93} 9$ U.S.C. $\& 4$ (1964) (emphasis added). See note 26 supra. The other procedural sections also assume federal.jurisdiction acquired independent of the Act itself. Sec 9 U.S.C. $\$ \S 3,5-13$ (1964); cf. note 94 infra.

94 It seems clear that the Act itself does not furnish federal question jurisdiction. The Lawrence court reached this conclusion, 271 F.2d at 408-09, as did the dissent in Prima, 388 U.S. at 420 \& n.24 (Black, J., dissenting). The courts and commentators are in general agreement with this proposition. See, e.g., Mengel Co. v. Nashville Paper Prods. \& Spec. Workers Union, 221 F.2d 644, 648 (6th Cir. 1955); Krauss Bros. Lumber Co. v. Louis Bossert \& Sons, 62 F.2d 1004, 1006 (2d Cir. 1933); Sturges \& Murphy, Some Confusing Matters Relating to Arbitration Under the United States Arbitration Act, 17 LAw \& CONTEMP. PRob. 580, 586 \& n.13 (1952). But see Note, 69 YaLe L.J. $847,861-63$ (1960). 
and cannot remove, he is prevented from resorting to the otherwise available federal remedy of the Act. Even if the substantive provisions of the Act were invoked to establish a concurrent original federal action, the federal anti-injunction statute would presumably prevent the resident defendant from successfully enjoining the state court proceeding. ${ }^{95}$ While the defendant might obtain a section 4 compulsion order in a federal court, 96 enforcement of the resultant award would be precluded if the state court reached a judgment in the interim. ${ }^{97}$ In numerous instances then, due to the dual jurisdictional requirements of the Act, the general removal statute, and the fact that the Act itself does not provide for separate federal question jurisdiction, a party may be forced to accept differing state and federal court treatment of a single cause of action. ${ }^{98}$

95 "A court of the United States may not grant an injunction to stay proceedings in a state court except as expressly authorized by Act of Congress, or where necessary in aid of its jurisdiction, or to protect or effectuate its judgments." 28 U.S.C. $\$ 2283$ (1964). The Arbitration Act does not grant the federal courts power to stay state court proceedings. Similarly, in enjoining' a state proceeding in order to compel arbitration under $\$ 4$ of the Act, a federal court would not be acting to protect or effectuate a judgment. Thus, the only one of the three conditions in $\$ 2283$ which might apply in this instance would be an attempt by a federal court to protect its jurisdiction. Moreover, since the statute is designed to prevent conflict between federal and state courts, see Leiter Minerals, Inc. v. United States, 352 U.S. 220, 225 (1957); Henson v. Hoth, 258 F. Supp. 33, 34-35 (D. Colo. 1966), it is generally maintained that the Act should be construed narrowly, see Baines v. City of Danville, 337 F.2d 579, 587-93 (4th Cir. 1964); T. Smith \& Son v. Williams, 275 F.2d 397, 402-07 (5th Cir. 1960). It is doubtful that the interest in comity would be outweighed by the interest in arbitration, particularly in light of the state interest in contracts generally. See text following note 104 infra. Thus, the third condition would also appear inapplicable. But see Fremont Cake \& Meal Co. v. Wilson \& Co., 86 F. Supp. 968 (D. Neb. 1949) (dictum), aff d, 183 F.2d 57 (8th Cir. 1950). The district court in Fremont reserved decision on this question, but the court of appeals intimated that, even if the plaintiff lad been entitled on the merits to specific performance of an arbitration agreerneut, the federal court was without power to provide this remedy once a state court action had been commenced. Id. at 60 .

${ }^{90} 9$ U.S.C. $\$ 4$ (1964). See note 26 supra and aceompanying text.

${ }^{97} \mathrm{Cf}$. Schonwald, Problems of Finality and Consistency in Commercial Arbitration Awards: The Role of Res Judicata and Collateral Estoppel, 22 ARB. J. 129, 136-37 (1967).

${ }^{88}$ A ready solution to the equal protection dilemma posed by Prima would be to allow reinoval to the federal courts iregardless of the citizenship of the parties. Such a result wonld be achieved under alternatives offered in recent re-examinations of federal jurisdiction. Commenting on an American Law Institute study (ALI Study of the Division of Jurisdiction Between State and Federal Courts, Official Draft No. 3, 1965), Professor Wright stated that the drafters felt that there was a need for uniformity as to federal questions, and, therefore, a defendant ought to be permitted to gain entrance to a federal court if he has a "federal defense." Wright, Federal Question Jurisdiction, 17 S.C.L. Rev. 660, 664-65 (1965). See also Dodge v. Woolsey, 59 U.S. (18 How.) 331, 354 (1855); The FEDERALIST No. 80, at 502 (B. Wright ed. 1961) (Hamilton). 
Prima differs from Erie since a federal statute, rather than a judicial rule, was the alleged source of discrimination and a federal remedy, not a state right was drawn into question. Consequently, in order to prevail on equal protection grounds, the resident must demonstrate that the Arbitration Act establishes an arbitrary classification of persons benefitted by the proffered remedy and that the classification is not reasonably related to the purpose of the statute. ${ }^{99}$ Section 2 of the Arbitration Act purports to validate written agreements to arbitrate contained in any contract involving interstate commerce. 100 Yet, by failing to provide that the Act itself would sustain federal jurisdiction, it is arguable that Congress arbitrarily discriminated against those parties whose contract affected interstate commerce but who lacked the Act's dual jurisdictional prerequisites. ${ }^{101}$ There would seen to be no rational basis for excluding arbitration agreements entered into by such persons since, presumably, these contracts would not be substantively distinguishable from agreeinents made by parties enjoying free access to the federal courts. Since Congress had the power to preempt the field of interstate contracts by virtue of the commerce clause, ${ }^{102}$ and enacted

A similar analysis has been offered by Wechsler, Federal Jurisdiction and the Revision of the Judicial Code, 13 LAW \& CONTEMP. PROB. 216, 233-34 (1948): "[It is] . . . far more logical [to grant] ... removal to defendants when they claim a federal defense against the plaintiff's state-created claim and to the plaintiff when ... . he relies by way of replication on assertion of a federal right. The need is to remember that the reason for providing the initial federal forum is the fear that state courts will vicw the federal right ungenerously." Id. (emphasis added). Logically then, while the Arbitration Act does not constitute a federal question, see note 94 supra, the Act could come within the terminology of a "federal defense" where utilized by a party to defend against a state cause of action. But see 1A J. Moore, Federal Practice II 0.157[1.-3], at 75 (removal statutes are strictly coustrued by the courts). Of course, the simplest solution to the problem posed by Prima would be for Congress to specify that if a state chooses to accept litigation concerned with arbitration of contracts affecting interstate commerce, it must adopt $\S \S 1$ and 2 as governing rules. Yet, there is no indication that congressional review of the Act is anticipated.

${ }^{99}$ See, e.g., McLaughlin v. Florida, 379 U.S. 184, 191 (1964) (classification must be "reasonable in light of [the statute's] purpose"); Bolling v. Sharpe, 347 U.S. 497, 500 (1954) (classification reasonably related to a "proper governmental objective"); Truax v. Raich, 239 U.S. 33, 42 (1915) ("reasonable classification implies action consistent with the legitimate interests of the State").

1009 U.S.C. \& 2 (1964).

${ }^{101}$ But cf. Guaranty Trust v. York, 326 U.S. 99, 105 (1945): "In giving federal courts 'cognizance' of equity suits in cases of diversity jurisdiction, Congress never gave, nor did the federal courts ever claim, the power to deny substantive rights created by State law or to create substantive rights denied by State law.

"This does not mean that whatever eqnitable remedy is available in a Stato court must be available in a diversity suit in a federal court, or conversely, that a fedcral court may not afford an equitable remedy not available in a State court."

${ }^{102}$ See Committee on Commerce, Trade and Coununercial Law, The United States Arbitration Law and Its Application, 11 A.B.A.J. 153, 155 (1925). 
language which seemingly would support enforcement of all arbitration provisions contained in interstate contracts, a judicial resolution which would leave some agreements at the mercy of contrary state law appears to be an unresponsive attempt to effectuate the policy of the Act. Arguably, however, such limitation on the scope of the Act can be rationalized as an accommodation of the significant state interest in the enforceability of contracts generally. There are indications in the legislative history of the Arbitration Act that Congress did not wish to "bludgeon" the states into adopting arbitration enforcement. ${ }^{103}$ Also, it seems arguable that Congress wished to lead by example in this field, hoping the states would enact similar legislation. ${ }^{104}$ Indeed the Act, by leaving the states free of federal domimation in an area of legitimate state concern, may be viewed as an attempted promotion of creative federalism. ${ }^{105}$ Thus, if unequal protection occurs, it results from the nature of federalism, and not froin an over-inclusive or an under-inclusive classification of persons afforded a remedy under an act of Congress. Even if the equal protection issue is avoidable, however, a significant "forum-shopping" problem remains as long as the Act is held applicable solely in the federal courts. The forum-shopping problem, together with the desirability of vindicating the policy of the Arbitration Act, argues in favor of applying the Act to the states in the manner of section 301 of the Taft-Hartley Act. 106 Yet, the history underlying the passage of the Arbitration Act is not comparable to the labor unrest which prompted the federal labor laws, and the national policy in favor of arbitration may not appear to be as compelling as that supporting effective collective bargaining. ${ }^{107}$ However, the majority opinion in Prima seems to lay the foundation for the refutation of this policy distinction. Except in those instances where the "making" of the arbitration provision itself is in issue, the doctrine of separability enunciated in Prima mandates the enforcement of broad arbitration provisions. By holding that Congress, through section 4 of the Act, explicitly directed the federal courts to apply this expansive doctrine in order to vindicate "the unmistakably clear congressional purpose that arbitration procedure . . . be speedy and

${ }^{103}$ See 388 U.S. at 420 \& n.23 (Black, J., dissenting); Joint Hearings Before the Subcomm. of the Comms. on the Judiciary on the Arbitration of Interstate Commercial Disputes, 68th Cong., 1st Sess., ser. 4, vol. 1, at 28, 39-40 (1924).

$104 \mathrm{rd}$.

${ }^{105}$ See 388 U.S. at $405-06$ n.13; notes 9 \& 28 supra. But see note 21 supra.

Since $\$ \$ 3$ and 4 of the Arbitration Act provide equitable remedies, Congress may also have hesitated to extend the Act to the states out of deference to the historical lack of equity powers in various state jurisdictions. Cf. 1-2 J. Moore, Federal Practice IIT 0.6[2.-2], at 216;2.03, at 314-15;2.09, at 440, 455-56 (1964).

${ }^{100}$ Labor-Management Relations Act (Taft-Hartley Act) $\S 301,29$ U.S.C. $\S 185$ (1964).

${ }^{107}$ See Note, 69 YALE L.J. 847, 859-60 (1960); cf. 46 VA. L. REv. 340, 342-43 (1960). 
not subject to delay and obstruction in the courts,"108 the Prima court has, in effect, determined that the congressionally expressed national policy in favor of arbitration is very strong indeed. Further, the danger of disparate state and federal court treatment of a federal remedy is presently as immediate in the arbitration context as that confronting the Supreme Court in its interpretation of section 301.109 The Arbitration Act is perhaps more readily interpreted as applicable to the states than is section 301 simce the latter provides only for the brimging of a suit in a federal court when there has been a violation of a labor contract. ${ }^{110}$ Section 2 of the Arbitration Act, on the other hand, states in substantive terms that all agreements covered by the Act are "valid, irrevocable, and enforceable," and is not framed simply in terms of providing access to the federal courts.111 In addition, Prima's endorsement of the Act as "national substantive law" would appear to be analogous to Supreme Court rulings in Textile Workers Union $v$. Lincoln Mills"12 and its progeny that section 301 of Taft-Hartley is "federal law," binding on the states. 113

Textually, the Arbitration Act lends itself to a bifurcated construction which would permit an extension of the Act to the states. Sections 1 and 2 do not refer to any particular court for the validation of contracts "involving commerce," and may be distinguished from the procedural portions which are addressed to the federal courts alone. Language in Bernhardt that the

108388 U.S. at 403-04.

${ }^{109}$ See Teamsters Local 174 v. Lucas Flour Co., 369 U.S. 95, 102-04 (1962) (state courts must apply federal law in suits under $\$ 301$ ); Comment, Development of the Scope of Section 301 of the Labor-Management Relations Act, 49 CORNELL L.Q. 81, 83-84 (1963).

${ }^{110}$ Labor-Management Relations Act (Taft-Hartley Act) $\$ 301,29$ U.S.C. $\$ 185$ (1964). Section 301 (a) states, in part: "Suits for violation of contracts between an employer and a labor organization. . . Inay be brought in any district court of the United States having jurisdiction of the parties, without respect to the amount in controversy or without regard to the citizenship of the parties." See note 22 supra.

111 See 9 U.S.C. $\$ 2$ (1964). See also note 22 supra and preceding text.

112353 U.S. 448 (1957).

113 Id. at 456; see, e.g., Teamsters Local 174 v. Lucas Flour Co., 369 U.S. 95 (1962); Teamsters Local 24 v. Oliver, 358 U. S. 283 (1959). There are additional examples of judge-made "federal law," which appear to contradict the pronouncement in Erie, 304 U.S. at 78, that there is no federal common law. See, e.g., Clearfield Trust Co. v. United States, 318 U.S. 363 (1943) (government commercial paper); Sola Elcc. Co. v. Jefferson Elec. Co., 317 U.S. 173 (1942) (anti-trust); Hinderlider v. La Plata River Co., 304 U.S. 92, 110 (1938) (apportionment of water in interstate streams); Dwinell-Wright Co. v. National Fruit Prod. Co., 140 F.2d 618 (1st Cir. 1944) (trademark infringenuent); cf. Comment, Hanna v. Plummer: An Expanded Concept of Federal Common Law-A Requiem for Erie?, 1966 Duke L.J. 142, 147. See generally 2 W. Crosskey, Polmics and the Constitution 912-20 (1953); Clark, State Law in the Federal Courts: The Brooding Omnipresence of Erie v. Tompkins, 55 YALE L.J. 267 (1946); Friendly, In Praise of Erie-and of the New Federal Common Law, 39 N.Y.U.L. REv. 383 (1964); Hill, supra note 68. 
sections of the Act are to be read as "integral parts of a whole"114 would not prevent such a dissection, if it is noted that Bernhardt read section 3 in terms of section 2 to determine the applicability of the former section. The scope of section 2 was not determined by the procedural remedies of section 3. ${ }^{115}$ Similarly, the Prima Court gauged the appositeness of sections 3 and 4 by the scope of section 2, and not vice versa. ${ }^{116}$ Therefore, sections 1 and 2 could be freely and entirely applied to the states. ${ }^{117}$

Reading the Arbitration Act in this disjunctive manner would undoubtedly be violative of the legislative scheme. It seems clear that the Act was intended to correct judicial antipathy toward arbitration in federal rather than state courts. 118 Indeed, all of the procedural clauses of the Act are addressed solely to the federal courts, and state court proceedings are not mentioned in the entire Act. Arguably, some distortion of original legislative intent is justified. Because of the intervention of Erie, the resultant emasculating implications of Bernhardt, and the failure of the states to pass uniform laws on arbitration to supplement the Act, the statutory plan to make all antecedent arbitration agreements valid has not been realized. ${ }^{119}$ In addition, subsequent decisions of the Supreme Court expanding the breadth of the commerce clause seriously weaken any need for an appeal to federalism, since the present desire is to have federal uniformity in most matters significantly affecting interstate commerce. ${ }^{120}$

114350 U.S. at 201.

${ }^{110}$ Id. at 201-02.

${ }^{216}$ See 388 U.S. at 401, 403-04.

${ }^{117}$ See 108 U. PA. L. Rev. 915, 920-21 \& n. 37 (1960). It has been observed that the problems implicit in leaving to the federal courts the task of formulating "arbitration law" are not as severe as those assumed by the courts under the Lincoln Mills decision. See 73 HARV. L. Rev. 1382, 1385 (1960).

Assuming the substantive rights of $\S 2$ are applicable to the states, the question remains whether the remedial sections of the Act must also be applied by the state courts. See generally Note, Scope of the United States Arbitration Act in Commercial Arbitration: Problems in Federalism, 58 Nw. U.L. REv. 468, $492-93$ (1963).

118 Joint Hearings, supra note 103, at 16-17, 37; H.R. REP. No. 96, 68th Cong., 1st Sess. 1 (1924); Baum \& Pressman, The Enforcement of Commercial Arbitration Agreements in the Federal Courts (pt.2), 8 N.Y.U.L.Q. 428, 459 (1931); Committee on Commerce, supra note 102, at 154; 73 HARV. L. REv. 1382, 1383 (1960); 108 U. PA. L. Rev. 915 (1960); Note, 69 Yale L.J. 847, 863 \& n.100 (1960); note 32 supra; cf. Bernheimer, The United States Arbitration Act, 3 DockET 2928 (1925).

${ }^{119}$ See Joint Hearings, supra note 103, at 16, 28 (statements of Mr. Cohen and Mr. Rose); Sayre, Development of Commercial Arbitration Law, 37 YAle L.J. 595, 616-17 (1928). Contra, Joint Hearings, supra note 103, at 39-40 (statement of Mr. Cohen).

120 See, e.g., Katzenbach v. McClung, 379 U.S. 294 (1964); Wickard v. Filburn, 317 U.S. 111 (1942). See also note 32 supra. The Arbitration Act clearly applies to arbitration agreements contained:in contracts involving commerce with foreigni nations. See 9 U.S.C. $\$ \$ 1-2$ (1964). In contracts between American and foreign corporations 
Thus, to avoid the forum-shopping difficulty and strengthen the significant national policy in favor of arbitration, the Supreme Court may extend at least sections 1 and 2 to the states.

there will very likely be at least diversity jurisdiction, and, therefore, there would be no difficulty in gaining access to the federal courts. Thus, Prima will likely have a significant impact on all international arbitration agreements involving American corporations, resulting in uniform enforeement of such agreements in the federal courts. See Comment, A New Approach to United States Enforcement of International Arbitration Awards, 1968 DUKE L.J. 258, 279 n.106. The statement of a 1925 commentator on the Act would now appear to be accurate: "[T] he statute . . . affects all agreements containing an arbitration clause made by residents of Britain or of the Continent of Europe which in any way relate to the manufacture, sale or delivery of merchandise within the United States . . . ." Gordon, International Aspects of Trade Arbitration, 11 A.B.A.J. 717 (1925). Moreover, the Prima decision, even without additional legislation, would appear to permit greater American participation in several existing bilateral commercial treaties, and, perhaps, in recent international arbitration conventions. See Report of the Comm. on Intl Unification of Private Law, 1960 A.B.A. Proceedinos (Int'1 \& Comp. L. Section) 202-07, 210, 217-33; Delaume, Convention on the Settlement of Investment Disputes Between States and Nationals of Other States, 1966 A.B.A. INT'L LAWYER 64. 